\title{
The Florida Master Gardener Program: History, Use, and Trends
}

\author{
Kathleen C. Ruppert, ${ }^{1}$ Joan Bradshaw, ${ }^{2}$ and Arlene Z. Stewart ${ }^{3}$
}

Adoitional INDEX words. volunteer, extension service

Summary. The Florida Master Gardener program volunteered more than 730,865 service hours to the Florida Cooperative Extension Service from 1991 through 1996 , valued as a net in-kind donation of $\$ 4,615,395$. Started in 1979, this program has grown consistently, affecting Floridians in all walks of life. Agents in 47 counties devoted an average of $29 \%$ of their time to capitalize on this volunteer knowledge and expertise. An overview of Florida's Master Gardener program provides a synopsis of the many components that make this volunteer program a success including past trends and current areas of review to prepare the program for the next millennium.

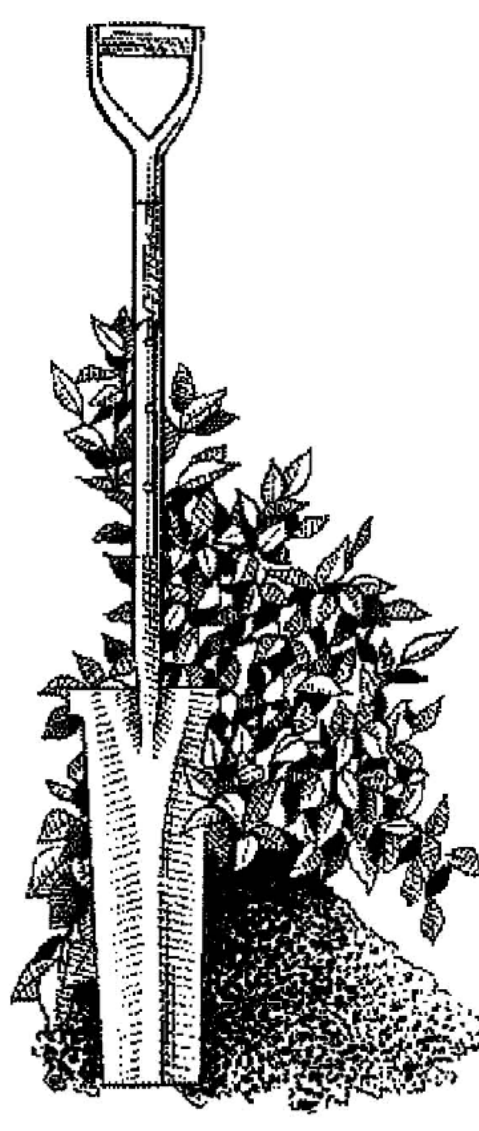

itizen needs and demands on extension increased greatly dur-
ing the late 1960s and 1970s when inflation drove residents to
cut costs in their personal budgets (Stephens and Delate, 1984). Although relatively inexpensive, food was considered a cost individuals could reduce by growing their own vegetables. These "inflation gardeners", immediately frustrated by their lack of basic gardening skills and knowledge, sought information and assistance from the Florida Cooperative Extension Service (FCES).

With this surge in home gardening, FCES became inundated with residential inquiries, and soon the growing demand for horticultural information exceeded staff capabilities. In response, FCES, sponsored by the Florida Seedsmen and Garden Supply Association, began a series of statewide garden supply store employee training in 1972 to assist in addressing home gardener concerns (Stephens and Delate, 1984). Although well received and extremely productive, it did not diminish the demands on FCES. Rather than reducing the telephone calls, the number of daily calls actually increased.

${ }^{1}$ Assistant professor, Department of Environmental Horticulture, University of Florida, Gaincsville, FL 32611-0670.

${ }^{2}$ Interim state Master Gardener coordinator, Department of Environmental Horticulture, University of Florida, Gainesville, FL 3261 10670 .

Educational materials designer, Florida Energy Extension Service, University of Florida, Gainesville, FL 32611-0570.

The cost of publishing this paper was defrayed in part by the payment of page charges. Under postal regulations, this paper therefore must be hereby marked advertisement solely to indicate this fact. 
By 1977 , FCES concluded that training garden store employees was not the most effective response to the demand for home gardening information (Stephens and Delate, 1984). Following a visit to the Master gardener (MG) program in the Pacific Northwest by three University of Florida (UF) extension specialists, FCES initiated a similar approach in 1979. Eighteen years later, this program has grown from the three original counties of Brevard, Dade, and Manatec with 58 certified volunteers to its present 47 counties (Fig. 1) with 816 new volunteers certified in the 1995-96 reporting year.

\section{Resident motivation to become MGs}

Many people vicw volunteers as individuals who just want to help others. In two open-ended informal surveys conducted in Fall 1993 during the MG annual conference and in Spring 1994 during a regional continued training program, $>50 \%$ of the MGs indicated that they decided to volunteer to learn more about gardening (education and self-knowledge). Studies in California and Idaho reflect similar findings (Grieshop, 1982; Simonson and Pals, 1990). The next highest recorded response was because they "love plants."

Mildred Smith (1996) recognized that, while volunteers provide valuable service, they are just as often the recipient of that service as well. In an electronic on-line digest for volunteer program managers, she wrote the following:

"...the field of volunteerism has become recognized as a professional arena of resource management...As [it] has advanced, so has the caliber of the volunteers...Traditionally, volunteers have been considered good-hearted individuals who volunteer out of some sense of altruism...Given the current quality of volunteers and the strategic positions in which many of them serve... we cannot assume that they are motivated solely by goodness..."

Thus, UF-Institute of Food and Agricultural Sciences (UF-IFAS) Cooperative Extension agents and specialists have cultivated MGs as resources for their communities and also as recipients of research-based information.

\section{Volunteer recruitment: A critical component for success}

Recruiting individuals with personal goals congruent with those of the volunteer program has long been recognized as one of the keys to success. To enlist suitable residents to train as MG volunteers, 43 coordinators currently interview or screen applicants. In many instances, the interview process involves other office staff members and veteran MGs.

In most counties, recruiting candidates for training is easy; in fact, many counties maintain a list of individuals who would like to attend their next training session. To assist with the problcm of seasonal volunteers, counties with a high number of part-time residents

Table 1. Comparison of Florida Master Gardener involvement in activities between 1989 and 1996.

\begin{tabular}{|c|c|c|c|}
\hline \multirow[b]{2}{*}{ Activity } & \multicolumn{2}{|c|}{$\begin{array}{c}\text { Counties reporting } \\
(\%)\end{array}$} & \multirow[b]{2}{*}{$\begin{array}{c}\text { Change } \\
(\%)\end{array}$} \\
\hline & $\begin{array}{c}1989 \\
(n=33)\end{array}$ & $\begin{array}{c}1996 \\
(n=46)\end{array}$ & \\
\hline Write or compile information for newsletters & 37 & 62 & 25 \\
\hline Set up exhibits & 63 & 79 & 16 \\
\hline Write or assist in writing news articles & 34 & 47 & 13 \\
\hline Conduct surveys & 26 & 38 & 12 \\
\hline Participatc in community gardens & 49 & 57 & 8 \\
\hline Assist or give demonstrations & 63 & 70 & 7 \\
\hline Conduct or assist with presentations & 77 & 83 & 6 \\
\hline Conduct home visits & 49 & 53 & 4 \\
\hline Conduct soil tests & 49 & 53 & 4 \\
\hline Perform landscape or maintenance projects & 69 & 72 & 3 \\
\hline Assist in writing publications such as fact sheets & 31 & 30 & -1 \\
\hline Answer phone questions & 86 & 83 & -3 \\
\hline Answer questions in office & 86 & 83 & -3 \\
\hline Appear on television programs & 31 & 26 & -5 \\
\hline Youth work & 71 & 66 & -5 \\
\hline Perform clcrical activities & 69 & 62 & -7 \\
\hline Answer questions or speak on radio shows & 23 & 15 & -8 \\
\hline Collect plant and insect specimens & 51 & 43 & -8 \\
\hline Act as judges for contests at fairs, ctc. & 66 & 53 & -13 \\
\hline Staff plant clinics & 80 & 66 & -14 \\
\hline
\end{tabular}




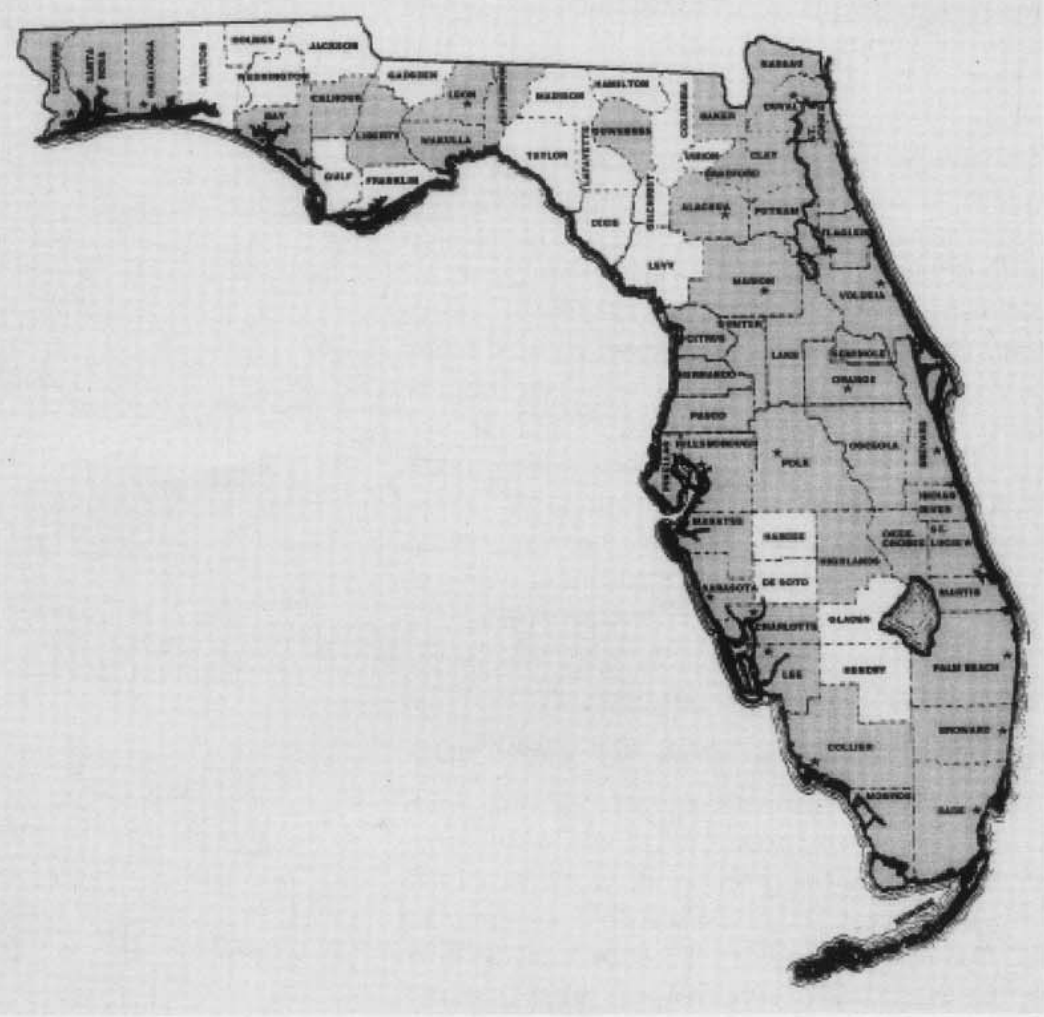

often hold their training during the off-season, ensuring that MGs will be available for assistance year-round.

Often recruitment has been so successful that MGs remain active long after their initial commitment has expired. This has resulted in less need to offer basic training with a concomitant increased need to focus on additional subject matter and updated training for veteran MGs.

\section{MG assistance to the extension service}

In the early years, the program's initial objective was to train MGs to answer repetitive, easily answered questions by phone or in person (Ruppert et al., 1988). Over the years this role has evolved considerably. Comparing 1989 MG roles with those in 1996, the greatest growth areas center around $\mathrm{MG}$ involvement in proactive and communityoriented ventures such as writing or compiling information for newsletters, setting up exhibits, writing or assisting in writing news articles, conducting surveys, participating in community gardens, and assisting or giving demonstrations (Table 1 ). In addition, other activities not reported in 1989 have become important, such as horticultural therapy, landscape design consultations using CD-ROM, Florida Yards and Neighborhoods advisement, and research assistance and county website development.
Fig. 1. Florida counties with active Master Gardener programs [represents a metropolitan area (World Book Encyclopedia, 1996)].

\section{Program administration in Florida}

Florida has 1350 miles of shoreline with the population primarily concentrated in 20 metropolitan areas (Fig. 1) (The World Book Encyclopedia, 1996). Population and subsequent needs vary from coastal to interior zones, urban to rural counties. For effective educational programming, counties require the latitude to design programs to meet their specific needs. Consequently, each county program is autonomous, although the program as a whole has a collective image and common history. Each county determines when and where they will train, how and what subjects they cover, and how they manage their volunteers. However, state leadership is necessary to provide continuity, communication, and resource maximization.

The state MG coordinator spearheads long-range planning, develops or assists in the development of educational materials, and fosters communication between county and state specialists. Additionally, the coordinator serves as a clearinghouse for scientific, administrative, and managerial resources for county agents and provides progress reports and impact information about the program to interested citizens, administrators, and researchers. The coordinator also forwards the latest research and technologies to county faculty and volunteers, promotes the use of technology to transfer information that benefits all customers of extension, and promotes or provides continuing education opportunities for program participants to maintain and increase horticultural knowledge throughout the state.

Currently, the 47 county programs are coordinated by 37 environmental horticulture agents and 10 agents with horticulture and other responsibilities. Of these, three positions are vacant. With the job market demand for horticultural professionals on the rise, the turnover rate of horticulture agents has also risen. Over the last few years, the state coordinator interacted with an average of 10 new agents each year, directing them to appropriate horticulture and related specialists and staff, offering guidance based on program history and experience and assisting in program development.

An advisory committee of county coordinators and horticultural specialists, representing different geographical and growing zones, assesses common needs of the program. One very beneficial activity of this group, which is 
chaired by the state coordinator, has been the development of the Florida Master Gardener Program Leader's Handbook, which contains ideas, the few state requirements, how to's, forms for ordering materials, and sample job descriptions (Ruppert, 1994).

\section{Training}

During the program's first 2 years, training sessions were taught primarily by extension specialists traveling from UF, Gainesville (Stephens and Delate, 1984). By the third year (1981), training sessions became so numerous and spontaneous that specialists could no longer participate in all of them. Today, county faculty either do most of the training themselves in their county or train jointly with two or more countics, often rotating the location each year. In a recent survey, 27 county coordinators indicated they train MGs in conjunction with other counties.

Due to climate and soil variations from northern to southern Florida, two training handbooks were developed addressing horticultural practices for north-central Florida and southern Florida. The basic training set includes one set of handbooks (three volumes), a copy of the Florida Lawn Hand$b o o k$, and 35 color insect identification sheets.

The variety of horticultural subject matter disseminated to the public requires excellent training of volunteers to ensure program quality. Basic training is a minimum of 50 hours.

To provide in-depth training to veteran MGs, UF's Gainesville campus has offered an annual 2-day Continued Training Conference. Since 1982, specialists, county faculty, and commercial nurserymen have presented in-depth instruction, research updates, and tours of UF facilities and ncarby arcas of horticultural interest.

MG training is also enhanced via county generated newsletters. Currently, 30 counties produce $M G$ newsletters, which allows county faculty an additional opportunity to present localized educational information to their volunteers. These efforts are complemented by a quarterly statewide newsletter, originating with the state coordinator, containing information from specialists and county faculty in and out of the state.

To assist agents in introductory and continued training of MGs, multiple copies of slide sets and videos are available through the IFAS film library. IFAS also provides CDROMs with information from the MG handbooks, plus other horticultural and nonhorticultural topics. Much of this information can also be accessed through http:// hammock.ifas.ufl.edu. Also available are separate UF CD-ROM plant selectors that allow individuals to choose from criteria such as growing zone, flower color, height, and predetermined landscape designs.

\section{Volunteer retention and reenlistment}

As mentioned previously, many volunteers remain active in the program long after they have served their original volunteer hours. Annual recertification requires an additional 6 hours of training, committing to an additional appropriate number of service hours (as determined by the county agent), and passing a brief horticultural test, if deemed necessary.

MGs seem to make a greater contribution to the daily operation of county offices as their experience and familiarity with the program and the FCES increases. Since 1989, more than 200 volunteers have remained actively involved with the program for 10 or more consecutive years. Of these, 21 have given 15 years of service.

\section{Award presentation and recognition}

A critical element of maintaining a volunteer program is to provide recognition for services rendered. Upon graduation or completion of their volunteer hours (depending on county requirements), MGs are provided with a certificate of completion, an engraved name badge, program identification card, and other items of recognition unique to the county, such as additional pins and shirts. Many counties now hold a special graduation ceremony or annual banquet to recognize MGs in their own county and have local government officials participate in the ceremony.

At the state level, MGs are eligible to receive 10-year UF service pins and 15-year plaques during a banquet at the Continued Training Conference. In addition, MGs are eligible to compete for state awards by entering one of the 12 Award of Excellence categories: beautification; demonstration garden; educational materials development; extension awareness; funny bone; general achicvement; outstanding MG; personal communications; service to $4-\mathrm{H}$ and other youth; special audiences; verbal mass communications; and written mass communications. Thesc awards require MGs to pursue the application process, describing in detail such things as the objective of the project and method of evaluation. The agent's only responsibility is to sign off on the award form that the project or activity did indeed take place and that it is the county's chosen submission for that category. The awards are judged anonymously by volunteers who have 
expertise or knowledge in the area of competition. These judges include specialists and administrators who then become more knowledgeable about services and activities of MGs throughout the state. All award pins, plaques, and certificates are funded through donations.

\section{Training evaluation}

Many counties evaluate the quality of their MG training program via short questionnaires at the end of the training program. More than $70 \%$ use a state and county faculty designed pre- and post-test survey (Knox et al., 1995), which reflects not so much the training but the change in practices as a result of what was learned (i.e., reduced water usage, correct mowing height, or less pesticide applied). If MGs apply the training they receive to their own environment, they probably will be stronger advocates of this information. Some counties evaluate the work of their MGs locally via follow-up phone calls to the clients served.

MGs also have the opportunity to evaluate the Continued Training Conference. This information is instrumental in providing subject matter recommendations for the following year's program.

\section{Program visibility and public relations}

The volunteers are customers of and very visible ambassadors for UF. From the continued involvement of these volunteers, one can extrapolate that, overall, they are extremely satisfied with the service extension has provided them. Additionally, the state's population at large has greater access to services through the efforts of these trained volunteers. Internally, county offices are able to maximize their resources, offer more services, and develop new programs because of this trained and dedicated labor pool.

UF-IFAS applied for and was awarded a service mark (a trademark used to denote a service rendered or offered) from the Secretary of State's Office for the title Florida Master Gardener. This and the development of a policy statement in conjunction with university attorneys has assisted greatly in maintaining the statewide image.

Networking with private enterprises to showcase UF's environmental horticulture program also enhances public relations and visibility for $M G$ programs across the continent. Since 1995 , the UF MG program has hosted an educational exhibit at EPCOT's International Flower and Garden Festival. At this year's 25th Anniversary celebration, MGs and agents from 14 counties will staff the 45 - day event. Florida residents and out-of-state visitors have an opportunity to learn more about environmental horticulture and related principles via the MGs.

In 1996, the Florida MG program received a Davis Productivity Award as "Volunteers in Action for Florida's Environment". This citizen-initiated and funded award program is administered by Florida TaxWatch in partnership with The Florida Council of 100. Annually it recognizes and rewards Florida state government's "productive unsung heroes" whose work measurably increases public service productivity and promotes innovation (Stampfli et al., 1996). The Davis Award further increased knowledge and understanding of the program throughout the state.

\section{The economics of the MG program}

Federal and state financial support continues to come under close scrutiny, making it more important than ever that FCES continue to maximize its resources through voluntecrs. As with any program, funds are needed for supplies and to support MG demonstration gardens, community vegetable gardens, and trial sites. To recoup some of these costs, more than $78 \%$ of the counties charge a fee in addition to the $\$ 35$ charge for the training materials. However, $40 \%$ of these counties refund the monies upon completion of some predetermined number of volunteer hours.

While of great assistance to FCES, county faculty have to dedicate a portion of their time to the training, management, and recertification of their voluntecrs. Since 1991, agents devoted an average of $29 \%$ of their time to the program or 603 hours per agent per year based on a 2080-hour work ycar, plus the time of specialists and the state coordinator. It is important to note that agents estimate they devote between $40 \%$ and $60 \%$ of their time to train their first group of volunteers (Ruppert, 1994).

The 1991-92 reporting year marked a breakthrough: volunteers since then have donated 100,000 hours yearly, for a grand total of 730,865 . The current MG program premise is that volunteers provide services that would normally fall to the agent. In 1995-96, volunteers donated 181,700 hours. If staff were hired to fill the same duties, at an average wage conservatively estimated at $\$ 9$ per hour plus $30 \%$ benefits, the cost would total $\$ 2,125,890$ for the year. Actual development and implementation costs for the MG program were $\$ 787,145$. This figure includes the $29 \%$ average agents' time and $30 \%$ benefits as well as the time of the state coordinator and part-time state program as- 
sistant. Therefore, net in-kind donation to the state is $\$ 2,125,890-\$ 787,145=$ $\$ 1,338,745$ for $1995-96$ and about $\$ 4,615,395$ from 1991-1996.

The long-term involvement by many of the volunteers has not only assisted horticulture programs but other components of FCES, as is often the case when county budgets are set and discussed. In some counties, MGs have served as a vocal constituency to tell county governments how much the program means to them as residents of the community. In some instances, county offices have been able to secure positions or receive additional funding for computers due to the efforts of these volunteers.

\section{Preparing for the future}

However successful the program is now, we cannot rest on the laurels of the past; instead we plan for the future. A comprehensive statewide review process is currently underway to determine how to keep the momentum going well into the next century. Areas of interest include

- defining the position of State Master Gardener coordinator

- defining the MG program in relation to state level support

- defining the status of the MG program as a state major program or a component of an environmental horticulture program

-identifying MG educational materials in and outside Florida

-identifying the most effective and efficient methods of presenting MG educational programs

-identifying funding mechanisms used to support the MG program and potential funding sources for future MG programs

-identifying in-service training needs of agents in relation to the $M G$ program

- reviewing and amending the state MG program policy statement

- identifying methods of evaluating state and county MG program impacts

-identifying appropriate organizational structure for effectively implementing the MG program.

\section{Summary}

Currently 2362 MGs promote environmental action and awareness and wise use of resources and reduced water, chemical, and energy usage in exchange for horticultural education provided by agents and specialists. The MG program continues to maximize the resources of staff and volunteers, while being an integral part of county extension programs in $70 \%$ of Florida's counties. Ultimately, the goal is to extend the vision of the UF-IFASprotecting and sustaining natural resources and environmental systems, enhancing the development of human resources, and improving the quality of human life through the development of knowledge in agricultural, human, and natural resources and making that knowledge accessible to the public at large.

\section{Literature cited}

Campbell, P.R. 1994. U.S. bureau of the census, current population reports, P25-1111, population projections for states, by age, sex, race, and Hispanic origin: 1993 to 2020. U.S. Government Printing Office, Washington, D.C.

Grieshop, J.I. 1982. Growing with Master Gardeners. Calif. Agr. 36(7):17-19.

Knox, G.W., A. Fugate, and G.D. Israel (eds.). 1995. Environmental landscape management: Use of practices by Florida consumers. Fla. Coop. Ext. Serv. Bul. 307. Univ. of Florida, Gainesville.

Ruppert, K.C. 1994. Florida Master Gardener program leader's handbook. Fla. Coop. Ext. Serv. Spec. Ser. ENH-001. Univ. of Florida, Gainesville.

Ruppert, K.C., J.M. Stephens, and R.J. Black. 1988. First nine years of the Florida Master Gardener program (1979-1987). Fla. Coop. Ext. Serv. Staff Rpt. Ser. ORH-88-3. Univ. of Florida, Gainesville.

Simonson, D.L. and D.A. Pals. 1990. Master Gardeners: Views from the cabbage patch. J. Ext. 28(2).

Smith, M.L. 1996. Volunteer program ethics: Defining standards of conduct. Puget Sound Volunteer Manager 2(5), Online networking for volunteer program managers, CYBERVPM @LISTSERV.AOL.COM.

Stampfli, S.R., D. Davis, H. Lee, K. Kaany, and C. Williams. 1996. The 1996 Davis Productivity Awards. 8th ed. Florida TaxWatch, Tallahassee.

Stephens, J.M. and K.M. Delate. 1984. Florida Master Gardener program: First five years. Proc. Fla. State Hort. Soc. 97:253-256.

The World Book Encyclopedia. 1996. vol. 7. World Book Inc., Chicago. 